\title{
Potential Changes in Watermelon (Citrullus lannatus) Ploidy Treated By Colchicine
}

\author{
Rd. Selvy Handayani1 ${ }^{*}$, Muhamad Yusuf 1, Ajmir Akmal² \\ ${ }^{1}$ Department of Agroecotechnology, Faculty of Agriculture, Universitas Malikussaleh, Aceh Utara, 24355, Indonesia \\ ${ }^{2}$ Department of Agricultural Industrial Technology, Faculty of Agriculture, Universitas Al Muslim. Bireuen, Indonesia \\ *Corresponding author: selvy@unimalac.id
}

\section{ARTICLE HISTORY}

\section{Received : 10 August 2018 \\ Revised : 27 August 2018 \\ Accepted : 11 September 2018}

\section{KEYWORDS}

Chromosome

Concentration

Seedless,

Stomata

Triploid

\begin{abstract}
The purpose of this study was to determine the effect of colchicine on changes in ploidy watermelon. The research was conducted in Agroecotechnology laboratory Universitas Malikussaleh, Microtechnique laboratory Agronomy and Horticulture Departement, Bogor Agricultural University, and Beuringen, Murah Mulia subdistrict, North Aceh. This research used Completely Randomized Design (CRD) two factors. The first factor was watermelon seed soaking time in colchicines $0,02 \%$ ie. $0,24,36$, and 48 hours. The second factor was the concentration of the colchicine solution on the sprout growth pointi.e. $0,0,1$, and $0,2 \%$. The results showed that plants were given colchicine became to shorter and fewer number of leaves than plants without any treatment. Colchicine could increase the size of the stomata, but it did not change the shape of stomata. Plants that were given colchicine had the potential to ploidy multiplication.
\end{abstract}

This is an open access article under the CC-BY-SA license.

\section{INTRODUCTION}

Watermelon is one of the fruits favored by the people of Indonesia so that the fruit has a very large demand on the market. Hybrid Watermelon is currently popular because of its various advantages in terms of its shape and quality and its sweet and fresh taste. There are several properties of hybrid watermelon that are popular among consumers.

The most demanding product is now seedless watermelons. Seedless watermelon is genetically watermelon which has 3 sets of chromosomes (triploid $=3 \mathrm{n}$ ). This can be obtained through the crosses between watermelon with chromosomes 4 sets (tetraploid $=4 \mathrm{n}$ ) with ordinary watermelon (watermelon with seed) which has chromosome 2 sets (diploid $=2 \mathrm{n}$ ). The problem is a four-celled watermelon plant should be produced artificially. Producing tetraploid chromosomes has to used biotechnology technique. There are many fruit plants used this technology for many purposes i.e. mangosteen (Handayani et. al, 2013) durian (Salasa et al 2013; Riupasa et al., 2015), and also watermelon.

Producing a tetraploid watermelon can be obtained by multiplying the diploid chromosomal set by using a colchicine solution (Elseth and Baumgardner, 1984). Colchicine $\left(\mathrm{C}_{22} \mathrm{H}_{26} \mathrm{O}_{6} \mathrm{~N}\right)$ is a white alkaloid obtained from the tuber Colchicum autumnale L. (Suminah, et al 2002). Colchicine is an alkaloid that affects the preparation of microtubules, so one of its impacts is to double the number of plant chromosomes (it causes polyploidy plant) (Haryanti et al, 2009; Takihara et al,, 2011).

Colchicine is often used to induce polyploidy plants. Colchicine can block the formation of spindle threads on cell division to form individual polyploids (Suminah, 2002; Ascough et al, 2008). The higher the concentration of colchicine, the higher the percentage of tetraploid cells but the percentage of germination deaths is also higher (Mansyurdin et al, 2002; Suryo 2007; Dhooghe et al, 2011).

Research on colchicine has done on watermelon (Ihsan et al., 2008), Simadu tangerine (Citrus nobilis) (Yuliantiti et al, 2014), onion (Allium sp) (Setowati et al., 2013). The research on colchicine on watermelon said that $0.2 \%$ of colchicine can change watermelon chromosome into tetraploid. Suryono (1993) reported that watermelon seed immersion in $0.02 \%$ colchicine solution for 30 hours and followed by a determination of $0.1 \%$ colchicine solution showed a polyploid tendency.

This research is part of a series of research on seedless watermelons. This study is aimed to analyze the influence of colchicine on the potential changes in ploidy plants and to determine the duration of immersion and concentration of effective colchicine penetration to change ploidy watermelon plants which can be seen from the changes in plant growth the size of stomata. 


\section{METHODS}

\subsection{Time and Place}

The research was conducted at Agroecotechnology Laboratory, Faculty of Agriculture, Universitas Malikussaleh and at farmer's garden in Beuringen Village, Mulia Subdistrict, North Aceh Regency, Indonesia. The observation of stomata size was done in the laboratory of Micro Engineering Department, Faculty of Agronomy and Horticulture, Bogor Agricultural University. The experiments were conducted from August to December 2013.

\subsection{Materials and tools}

Materials used in this research were F1 Sea Dragon hybrid seeds, colchicine, distilled water, cotton, tissue, nail polish, planting medium, fertilizers, and pesticides. Fertilizers and pesticides used are manure, NPK Mutiara, Dithane M-45, Furadan, and Decis. The materials used were pipettes, tweezers, knives, cutters, measuring cups, stirrer rods, Erlenmeyers, digital scales, gloves, and masks. The materials used for sowing the watermelon seeds were trays, label papers, straps, and masking tapes. Microscopic observations of stomata were using Petri dishes, brushes, glass cover, and an Olympus BX51 microscope.

\subsection{Research methods}

This study used Randomized Block Design (RBD) with two 2 factors. The first factor was the duration of soaking of the seeds in $0.02 \%(\mathrm{~L})$ colchicine solution at $0,24,36$, and 48 hours. The second factor was the concentration of the solution of colchicine solution at the germinating point of watermelon plants $(\mathrm{P})$ which were $0.0,0.1$, and $0.2 \%$. There were 12 treatment combinations with 3 replications. There were 36 experimental units. Each unit of the experiment was a bed consisting of 8 plants per bed.

\subsection{Preparation in Laboratory}

The medium used to sow the seeds was sterilized at a temperature of $150{ }^{\circ} \mathrm{C}$ for 3 hours. The seed used was immersed with fungicide for 5 minutes, and then it has washed clean with running water. This activity needed to be done so that the seeds were free from fungi that can disrupt plant growth.

\subsection{Colchicine soaking}

The seeds that have been soaked in a fungicide solution were then placed in petri dishes that have been layered with cotton. Each petri dish consists of 30 seeds of watermelon, and the solution of $0.02 \%$ colchicine was given $30 \mathrm{ml}$ per petri dish. Petri dishes were closed and placed in a place protected from direct sunlight. The length of soaking of the seeds was carried out according to the treatments. The purpose of using cotton to layer the Petri dishes so that the entire surface of the seed may be exposed to a colchicine solution but the seeds were not completely immersed in the solution. It helped to multiply the chromosomes but the seeds still have enough oxygen.

\subsection{Seedlings and Dropping the Colchicine}

The seeds from each treatment in each petri dish needed to be washed for several times to keep them clean. The clean seeds had to be planted immediately in trays which previously have been filled with sterile planting medium. The seeds were allowed to grow for 1 week or until the first leaves appeared. The dropping of colchicine was done at the growing point. It was done according to the treatments.

The colchicine was dropped 6 times for 4 days. The amount of dropping was 1 drop per plant. The first dropping was done in the evening (5 pm). The second and third droppings were done in the morning $(7 \mathrm{am})$ and evening (5 pm). The fourth and fifth droppings were done on the fourth day in the morning $(7 \mathrm{am})$. Colchicine is volatile if being exposed with sunlight. Therefore, the droppings were done in the morning and evening so that the colchicine solution could not evaporate easily and the treatments could be done well.

\subsection{Field Preparation}

The field was cleared from weeds and the remaining plants which could disrupt the plant growth. The field was sprayed and manure was given $2 \mathrm{~kg}$ per hole. The black plastic mulch was set and perforated $1 \times 1 \mathrm{~m}$. This activity was done 2 weeks before planting, 36 beds were made, 1 bed was for 1 treatment with the bed width was $4 \times 2 \mathrm{~m}^{2}$ and length $50 \mathrm{~cm}$ and range between beds is $30 \mathrm{~cm}$.

\subsection{Plantation}

The seeds treated with colchicine and have 2-4 leaves were then moved into the bed, one bed for one hole. The seeds were taken with care by bringing the seed medium from the trays and then planted in the planting hole. Each bed and treatment was labeled or marked as its important identity for observation.

\subsection{Fertilization}

The manure was given two weeks before planting, $2 \mathrm{~kg}$ per plant. NPK Mutiara was carried out 10 days after planting and repeated every two weeks. The concentration of NPK Mutiara was 5 grams/10 liters of water, each plant got $200 \mathrm{ml}$ of fertilizer solution.

\subsection{Maintenance}

Plant watering is done every day in the morning. The soil moisture needs to be maintained so that the soil was not too moist or too dry. Flooded watermelon plants are vulnerable to diseases, such as fusarium wilt. The beds need to be cleaned from weeds. Weeding is done twice during the planting period. Plant propagation was arranged so that the plants grew well and could be easily harvested.

\subsection{Harvesting}

The watermelons were harvested after 3 months. The ripe ones could be identify from their yellow or dry stalk. 
Harvesting needed to be done carefully in order to prevent the fall or displacement. The fruits were labeled with their treatments and plant numbers.

\subsection{Observation}

The observations were made on plant height, the number of leaves, the weight of fruits, shape, and diameter of stomata. The observation of shape and diameter of stomata was using Microscope Olympus BX51, digital camera, microscope type DP25, and software DP2-BSW.

The data of observations were subjected to statistical analysis using Analysis of Variance (ANOVA) at 0.05 probability level were significant difference existed means separated by Duncan's Multiple Range Test (DMRT).

\section{RESULTS AND DISCUSSION}

\subsection{Results}

The ANOVA results showed that there was an interaction between the length of seed soaking in colchicine and the concentration of dropping colchicine to the length of plants, the number of leaves and the weight of fruits. The results of ANOVA between two factors were described in Table 1.

Table 1. The effect of colchicine treatment to the length, number of leaves, stem diameter and weight of fruit of watermelon plants

\begin{tabular}{ccccc}
\hline Treatments & $\begin{array}{c}\text { Length } \\
\text { (cm) }\end{array}$ & $\begin{array}{c}\text { Number of } \\
\text { leaves }\end{array}$ & $\begin{array}{c}\text { Stem } \\
\text { diameter } \\
(\mathrm{cm})\end{array}$ & $\begin{array}{c}\text { Weight of } \\
\text { fruit } \\
(\mathrm{g})\end{array}$ \\
\hline L0P0 & $222,67 \mathrm{a}$ & $43,00 \mathrm{a}$ & $0.88 \mathrm{a}$ & $2,37 \mathrm{~cd}$ \\
L0P1 & $159,67 \mathrm{~b}$ & $27,00 \mathrm{c}$ & $0.71 \mathrm{a}$ & $2,50 \mathrm{bcd}$ \\
L0P2 & $166,67 \mathrm{~b}$ & $31,33 \mathrm{bc}$ & $0.79 \mathrm{a}$ & $2,23 \mathrm{dc}$ \\
L1P0 & $166,33 \mathrm{~b}$ & $30,00 \mathrm{bc}$ & $0.95 \mathrm{a}$ & $2,13 \mathrm{~cd}$ \\
L1P1 & $183,33 \mathrm{~b}$ & $34,00 \mathrm{abc}$ & $0.72 \mathrm{a}$ & $2,83 \mathrm{abc}$ \\
L1P2 & $170,67 \mathrm{~b}$ & $32,00 \mathrm{bc}$ & $0.76 \mathrm{a}$ & $2,77 \mathrm{abc}$ \\
L2P0 & $171,00 \mathrm{~b}$ & $37,00 \mathrm{abc}$ & $1.11 \mathrm{a}$ & $2,23 \mathrm{~cd}$ \\
L2P1 & $206,67 \mathrm{a}$ & $37,00 \mathrm{abc}$ & $1.22 \mathrm{a}$ & $2,70 \mathrm{abc}$ \\
L2P2 & $174,33 \mathrm{~b}$ & $31,00 \mathrm{bc}$ & $0.99 \mathrm{a}$ & $2,27 \mathrm{~cd}$ \\
L3P0 & $169,00 \mathrm{~b}$ & $37,00 \mathrm{abc}$ & $1.38 \mathrm{a}$ & $1,73 \mathrm{~d}$ \\
L3P1 & $174,00 \mathrm{~b}$ & $32,67 \mathrm{bc}$ & $1.52 \mathrm{a}$ & $2,37 \mathrm{~cd}$ \\
L3P2 & $166,00 \mathrm{~b}$ & $30,00 \mathrm{bc}$ & $1.08 \mathrm{a}$ & $3,57 \mathrm{a}$
\end{tabular}

Note: Means in the same column followed by the same letters do not differ significantly $(P=0.05)$ as determined by Duncan's multiple range test. $L O=0$ hour; $L 1=24$ hours; $L 2=36$ hours; $L 3=$ 48 hours; $P 0=0 \%$ of colchicine; $P 1=0.1 \%$ of colchicine; $P 2=0.2 \%$ of colchicine.

Results given in Table 1 described the effect of colchicine on the watermelon plants. The treatment of colchicine to the plants tends to inhibit their growth not only the length but also the leaves. The number of leaves and the length of plants without colchicine treatment were higher than the plants with colchicine treatment. For the fruit weight, it showed that watermelon treated with $48 \mathrm{~cm}$ colchicine with a concentration of $0.2 \%$ (L3P2) had the highest fruit weight value compared to other treatments. Colchicine treatment was statistically unaffected in the diameter of the fruit, but on average the plants treated with colchicine generally had a larger diameter.
Colchicine significantly affected the leaf stomata size (Table 2). The interaction between the two colchicine factors was revealed in the diameter of the longitudinal and transverse stomata. The longest diameter of longitudinal stomata was achieved in 48 hours with colchicine treatment with a concentration of $0.1 \%$ (L3P1), even though it was not significantly different from the 48-hour colchicine treatment with a concentration of $0.2 \%$ (L3P2). The longest diameter of transversal stomata was achieved in a 24 -hour colchicine treatment with $0.1 \%$ of concentration (L1P1), but not significantly different from the other treatments, except in the absence of colchicine (LOP0) and treatment of $0.1 \%$ colchicine (LOP1).

Table 2. The effect of length of soaking and the application of colchicine to stomata diameter of watermelon plants.

\begin{tabular}{ccc}
\hline \multirow{2}{*}{ Treatments } & \multicolumn{2}{c}{ Diameter of stomata } \\
& Longitudinal $(\mu \mathrm{m})$ & Transversal $(\mu \mathrm{m})$ \\
\hline L0P0 & $16,503 \mathrm{f}$ & $9,574 \mathrm{de}$ \\
L0P1 & $20,824 \mathrm{e}$ & $8,712 \mathrm{e}$ \\
L0P2 & $23,172 \mathrm{cde}$ & $17,265 \mathrm{abc}$ \\
L1P0 & $25,251 \mathrm{bcd}$ & $16,667 \mathrm{abc}$ \\
L1P1 & $23,992 \mathrm{cde}$ & $20,627 \mathrm{a}$ \\
L1P2 & $23,177 \mathrm{cde}$ & $16,763 \mathrm{abc}$ \\
L2P0 & $22,437 \mathrm{de}$ & $15,907 \mathrm{abc}$ \\
L2P1 & $26,324 \mathrm{bc}$ & $19,315 \mathrm{ab}$ \\
L2P2 & $26,618 \mathrm{bc}$ & $18,235 \mathrm{ab}$ \\
L3P0 & $24,612 \mathrm{bcd}$ & $12,788 \mathrm{cde}$ \\
L3P1 & $30,142 \mathrm{a}$ & $14,145 \mathrm{bcd}$ \\
L3P2 & $27,109 \mathrm{a}$ & $16,910 \mathrm{abc}$ \\
\hline
\end{tabular}

Note: Means in the same column followed by the same letters do not differ significantly $(P=0.05)$ as determined by Duncan's multiple range test. $L O=0$ hour; $L 1=24$ hours; $L 2=36$ hours; $L 3=$ 48 hours; $P 0=0 \%$ of colchicine; $P 1=0.1 \%$ of colchicine; $P 2=0.2 \%$ of colchicine.

There was an interaction between length of soaking and concentration of dropping colchicine. The application of colchicine affected the size of stomata. However, the forms of stomata were not changed with the application of colchicine. It has been described in Figure 1.

\subsection{Discussion}

The results of the observation of plant growth showed that the treatment of colchicine can decrease the growth rate of watermelon plants. Plants without treatments generally have higher results in height and number of leaves than those treated with colchicine (Table 1). This is in accordance with the research of Banowo (2001) and Haryanti et al. (2009), which stated that the growth of green bean plants showed lowered response with increasing concentration of colchicine. It is characterized by shorter plants, slower growth curves, and longer flowering age. Similarly, the number of leaves, wet weight, and dry weight of plants have decreased at high colchicine concentrations. In sugar apple (Annona squamosa L.) plants, colchicine gave effects to some morphological properties of early plant growth, such as the plant becomes shorter (Dwijayanti (2012). The same response is on tangerine (Julian et al., 2014), Gossypium arboretum L (Rauf et al, 2006), Platanus acerifolia (Liu et 
al., 2007), dragonhead (Omidbaigi et al., 2010), and Pelargonium x hortorum (Jadrna et al., 2010).

The application of colchicine was able to increase stem diameter and fruit weight. Watermelon plants which treated with colchicine have stem diameter and greater fruit weight than without colchicine (Table 1). These results were in agreement with the research obtained by Burns (1972) He reported that the presence of different morphological features in polyploid plants than its diploid plants. In polyploid plants, the larger number of chromosomes causes the cell size and cell nucleus to grow larger. Larger cells produce larger parts of the plant such as leaves, flowers, fruits, and plants. This reinforces the indication that watermelon plants treated with colchicine have changed the chromosome set from diploid to tetraploid.

The results of observations on the stomata of watermelon showed that the stomata forms did not change despite being treated by colchicine (Figure 1). However, the size of the stomata treated with colchicine was significantly improved (Table 2). For untreated plants (LOP0), the length of stomata (longitudinal) was smaller than other treatments. This was significantly different compared to the L3P0 treatment (48 hours of pre-treated soil and $0 \%$ of concentration), L3P1 (seeds soaked for 48 hours and $0.1 \%$ of concentration), and L3P2 (seeds soaked for $36 \mathrm{~h}$ and concentration of $0.2 \%$ ). Similarly, for the untreated plants (LOP0), the size of stomata (transverse) was smaller than other treatments. Fitdian (2006) also reported that orchid plants showed that the concentration of colchicine solution significantly affects the size of stomata. The results of colchicine treatments on the arrowroot (Maranta arundinacea L.) plants resulted in stomata length exceeding the average length of normal stomata. The same response is on Glycyrrhiza glabra var. glandulifera and Carthamus tinctorius L (Moghbel et al, 2015). The higher the ploidy level of the chromosome the greater the size of stomata (Sukamto et al., 2010). Stomata length (longitudinal and transversal) as a measure of stomata size can be an indicator of ploidy levels and it has been used in different plant types for determining ploidy levels (Moghbel et al., 2015).

The results of colchicine and observation studies on several variables have shown a positive and promising outcome. Comparison and observations of the tetraploid plants indicate that the watermelon plants which treated with colchicine could successfully multiply the chromosome set from diploid to tetraploid.

\section{CONCLUSION}

The application of colchicine on watermelon plants has decreased the growth of the plants. Colchicine caused dwarf and a lesser number of leaves than the untreated plants. The application of colchicine increased the weight of fruit and the size of stomata but did not change the form of stomata. The application of colchicine for 48 hours with a concentration of $0.2 \%$ (L3P2) can potentially alter the chromosome of the plants.
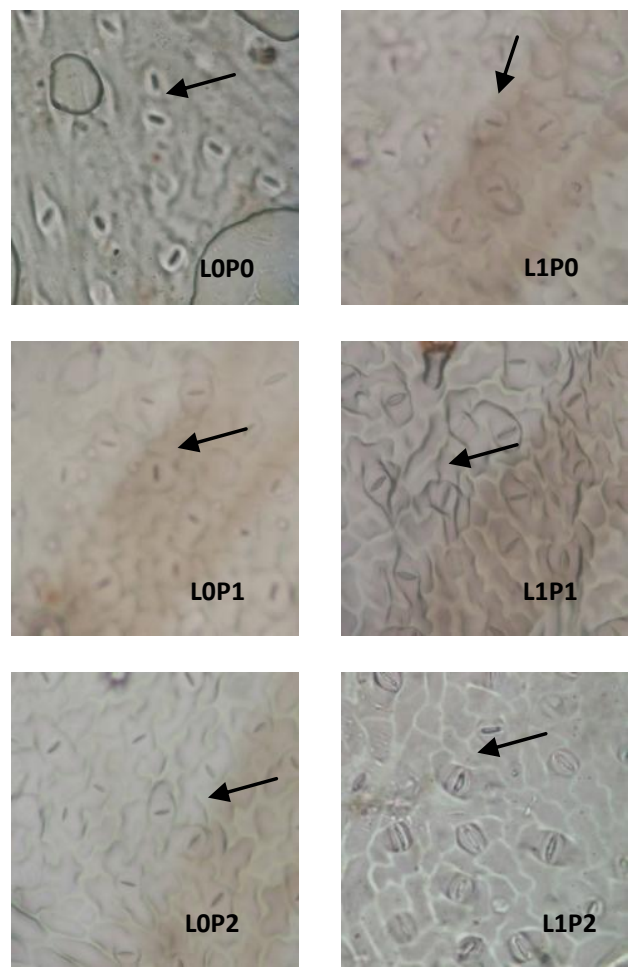
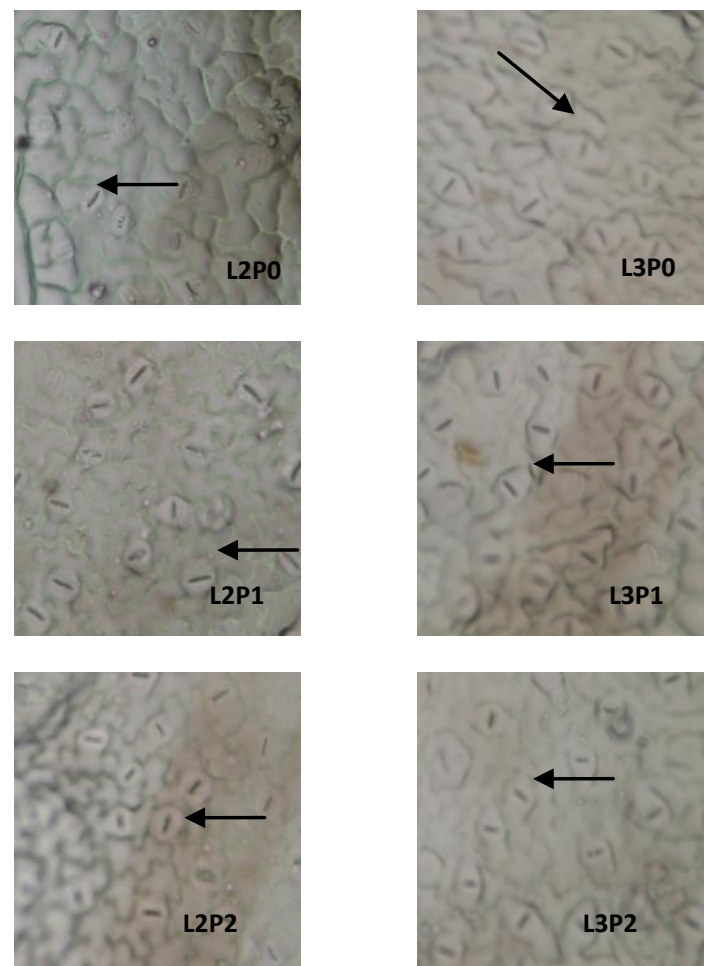

Figure 1. The forms of stomata affected by colchicine treatments. $L O=0$ hour; $L 1=24$ hours; $L 2=36$ hours; $L 3=48$ hours; $P 0=0 \%$ of colchicine; $P 1=0.1 \%$ of colchicine; $P 2=0.2 \%$ of colchicine. 


\section{REFERENCES}

Ascough, G.D., J. van Staden, J. E. Erwin. 2008. Effectiveness of colchicine andoryzalin at inducing polyploidy in Watsonia lepida N.E. Brown. HortSci. 43: 2248-2251.

Banowo, A. 2001. Pengaruh Kolkisin Terhadap Pertumbuhan Dan Produksi Kacang Hijau (Vigna radiate (L) Wilczek). [Thesis]. Diponegoro University. Semarang.

Burns, G. W. 1972. The Science of Genetics, an Introduction to Heredity. The Macamillan Company. New York. USA.

Dhooghe, E. K., van Laere, L. Eeckhaut, L. Leus, J. van Huylenbroeck. 2011. Mitotic chromosome doubling of plant tissues in vitro Plant Cell Tiss. Organ Cult. 104:359-373.

Dwijayanti, I. 2012. Pengaruh kolkisin terhadap fenotipe pertumbuhan awal dan jumlah kromosom tanaman srikaya (Annona squamosa Linn.). [Thesis]. Universitas Sebelas Maret, Surakarta.

Elseth, G. D., K. D. Baumgardner. 1984. Genetics. Addison-Wesley Publishing Co. Inc. 780 p. Canada.

Fitdian, G A. 2006. Pengaruh Pemberian Colchicine Pada Tanaman Anggrek (Phalaenopsis amboinensis). [Thesis\}. Universitas Muhammadiyah. Malang.

Handayani, R. S., R. Poerwanto, Sobir, A. Purwito, T. M. Ermayanti. 2013. Pengaruh Batang Bawah dan Jenis Tunas pada Mikrografting Manggis (Garcinia mangostana) secara In Vitro. J. Agron. Indonesia 41 (1) : 47 - 53.

Haryanti, S. R. B., Hastuti, N. Setiari, A. Banowo. 2009. Pengaruh Kolkisin Terhadap Pertumbuhan, Ukuran Sel Metafase dan Kandungan Protein Biji Tanaman Kacang Hijau (Vigna radiata (L) Wilczek) Jurnal Penelitian Sains \& Teknologi. 10 (2) : 112 - 120.

Ihsan, F., A. Wahyudi, Sukarmin. 2008. Pembentukan Semangka Tetraploid untuk Perakitan Semangka Tanpa biji. Buletin Teknik Pertanian. 13(2): 75-78.

Jadrna, P., O. Plavcova, F. Kobza. 2010. Morphological changes in colchicine-treated Pelargonium x hortorum L.H. Bailey greenhouse plants. Hort. Science. 37:27-33.

Liu G, Z. Li, M. Bao. 2007. Colchicine-induced chromosome doubling in Plantanus acefolia and its effect on plant morphology Euphytica. 157:145-154.

Mansyurdin, Hamru, D. Murni. 2002. Induksi Tetraploid Pada Tanaman Cabai Merah Keriting dan Cabai Rawit Dengan Kolkisin. Stigma. 12 (3) : $29-300$.

Moghbel, N., M. K. Borujeni, F. Bernard. 2015. Colchicine effect on the DNA content and stomata size of Glycyrrhiza glabra var. glandulifera and Carthamus tinctorius L. cultured in vitro Journal of Genetic Engineering and Biotechnology. 13: 1-6.

Omidbaigi, R., S. Yavari, M. E. Hassani, S. Yavari. 2010. Induction of autotetraploidy in dragon head (Dracocephalum moldavica L.) by colchicine treatment. J. Fruit Ornam. Plant Res. 18:23-35.

Rauf, S., I. A. Khan, F. A. Khan. 2006. Colchicine-induced tetraploidy and changes in allele freguencies in colchicine-treated populations of diploid assessed with RAPD markers in Gossypium arboretum L. Turk J. Biol. 30: 93-100.

Riupassa, P. A., T. Chikmawati, Miftahudin, Suharsono. 2016. The Molecular Diversity-based ISSR of Durio tanjungpurensis Originating from West Kalimantan, Indonesia. Makara J. Sci. 19 (1): 27-36

Salasa, N., K. Arum, S. Ashari, N. Herlina. 2013. Identifikasi tanaman durian (Durio zibethinus Murray) mirip durian varietas Bido di Kecamatan Wonosalam Kabupaten Jombang dengan metode isozim dan morfologi. Jurnal Produksi Tanaman. 1 (5): 427-433.

Setyowati, M., E. Sulistyaningsih, A. Purwantor. 2013. Induksi Poliploidi Dengan Kolkisin Pada Kultur Meristem Batang Bawang Wakegi (Allium x wakegi Araki). Jurnal Ilmu Pertanian. 16 (1): 58 -76.

Sukamto, L. A., F. Ahmad, A. H. Hawo. 2010. Pengaruh Oryzalin Terhadap Tingkat Ploidi Tanaman Garut (Maratana arundinacea L.) Bul. Littro. 21 (2): 93 - 102
Suminah, A. D. Sutarno, Setyawan. 2002. Induksi poliploidi Bawang Merah (Allium ascalonicum L.) Dengan Pemberian Kolkisin Biodiversitas. 3 (1) : $174-180$

Suryo, H. 2007. Sitogenetika. Universitas Gajah Mada Press. Yogyakarta.

Suyono H, Sutjahjo, A. Makmur, N. Tripudayani, U. Hafid. 1993. Induksi Tetraploid Pada Tanaman Semangka (Citrullus lanatus (Thunb). Bul. Agr. 21 (1): 55-61

Takahira, J., A. Cousin, M. N. Nelson, W. A. Cowling. 2011. Improvement in efficiency of microspore culture to produce doubled haploid canola (Brassica napus L.) by flow cytometry. Plant Cell Tiss. Organ Cult. 104: 51-59.

Yulianti, F., A. Purwito, A. Husni, D. Dinarti. 2015. In Vitro Induction of Tetrapbid in Simadu Tangerine (Citrus nobilis Lour) ShootTip Using Colchicine. J. Agron. Indonesia. 43 (1) : 66- 71. 